\title{
Effects of Sequential Sodium Hydroxide Ultrasonication and Hot Water Treatment of Rice Straw and Coconut Shell on Biogas Production
}

\author{
Antonio-Abdu Sami M. Magomnang ${ }^{1,2 *}$ and Sergio C. Capareda ${ }^{2}$ \\ 'Mechanical Engineering Department, University of Science and Technology of Southern Philippines - Cagayan de \\ Oro Campus, CM Recto Avenue, Lapasan, Cagayan de Oro City, Philippines; a_magomnang@yahoo.com \\ ²Biological and Agricultural Engineering Department, Texas A\&M University, College Station, Texas, USA; \\ scapareda@tamu.edu
}

\begin{abstract}
Objectives: This study aims to determine the effects of various pretreatment methods on the biomass properties and biogas yield in the anaerobic co-digestion of agricultural biomass waste co-digested with different biomass feedstocks for power generation applications. Methods: This study was carried out in order to determine the effects of the methane production on the two pre-treatments ( $3 \%$ and $4 \% \mathrm{w} / \mathrm{v} \mathrm{NaOH}$ ) subjected to sequential $\mathrm{NaOH}$-ultrasonication and Liquid Hot Water treatment for the rice straw and coconut shell feedstocks, which can be used as substrates for the anaerobic co-digestion experiments; using cow manure, digested manures and sewage sludge as inoculant. Findings: Results showed that the methane production increased by $140 \%$ and $290 \%$ from the pre-treatment of rice straw and coconut shells, respectively. With these, the pre-treated coconut shell subjected to ultrasonication with $3 \% \mathrm{NaOH}$ and Liquid Hot Water has the best effect among the pre-treatment of biomass feedstocks of rice straw and coconut shell at various $\mathrm{NaOH}$ concentrations. Applications: The results of this experiment would give a viable estimate on the possible methane production from codigestion of these resources. The enhancement of the biogas yield was attributed to the improvement of biodegradability of rice straw and coconut shell through the pre-treatments. The changes of chemical compositions, chemical structures, and physical characteristics made rice straw and coconut shell feedstocks become more available and biodegradable and thus were responsible for the enhancement of the biogas yield. These results are contributing to develop a feasible biogas production from rice straw and coconut shell.
\end{abstract}

Keywords: Anaerobic Digestion, Biogas, Cattle Manure, Coconut Shell, Rice Straw, Sewage Sludge

\section{Introduction}

Renewable energy produced from lignocellulosic materials (i.e. agriculture and forest residues), non-food crops (i.e. algae and grasses) or industrial waste and residue streams have considerably lower Greenhouse Gas emissions (GHGs) due to its closed carbon cycle. The use of second generation feedstocks will diminish the concern over competition between foods versus fuel and will lessen the potential impact on food supply (i.e. food prices, land competition and others). At present, feedstocks from the municipal solid waste, industry, food processing plants and wastewater treatment plant, are limited; thus, new renewable sources are sought after. With the abundant availability of agricultural biomass in the Philippines makes it a highly interesting source of feedstock, from a variety of crops like palay, corn, sugarcane, cassava and coconut and from livestock manure of carabao, cattle, hog, goat and dairy, that can be utilized for biogas production. These sources can serve as fuel for power generation or as feedstock for advanced biofuels production. Given these abundant supplies of biomass in the country, it would be advantageous for the Philippines to exploit these resources to address the country's energy 
dependence, mitigate climate change and eventually achieve economic growth and prosperity.

Biogas is a renewable, high-quality fuel which can be produced from various organic raw materials and used for various energy services. Biogas technology has been developed and widely used over the world because it has several advantages - reduction of the dependence on non-renewable resources, high energy-efficiency, environmental benefits, available and cheap resources to feedstock, relatively easy and cheap technology for production and extra values of digestate as a fertilizer ${ }^{1}$. However, the current status of biogas production and utilization varies largely among continents. To overcome the issues related to the utilization of lignocellulosic materials like rice straw and coconut shell for biogas production, new pretreatment strategies have been evaluated and developed. One of these strategies is the combination of sodium hydroxide hydrolysis, ultrasonication and Liquid Hot Water pretreatment. Typically, the ultrasonication and Liquid Hot Water pretreatment were used to modify the lignin and cellulose structure of the biomass to generate ethanol ${ }^{2}$ but for this case, said pretreatments were done to improve biogas yield. In a study by sodium hydroxide hydrolysis was found to substantially increase the biogas yield of rice straw.

Currently, there are many researches on the pretreatment of biomass wastes similar to paddy straw using sodium hydroxide-microwave pretreatment of ${ }^{3}$ it was reported that $4 \% \mathrm{NaOH}-30$ min microwave was found to be the best pretreatment which resulted in $65.0 \%$ decrease in lignin content and $88.7 \%$ reduction in silica content that resulted in $54.7 \%$ increase in biogas production ${ }^{3}$. Moreover, a mechanical disruption of algae using ultrasound homogenizer and thermo-alkaline pretreatment enzymatic hydrolysis demonstrated the best biogas yield than other pre-treatment which reached $626.5 \mathrm{~mL} / \mathrm{g}$ COD with $62.65 \%$ of biodegradability ${ }^{4}$. Furthermore, Liquid Hot Water pretreatment of giant reed in a Parr reactor and alkaline pretreatment was studied using the various $\mathrm{NaOH}$ concentrations which improve glucose yield that is significantly increased the cumulative methane yield by $63 \%$ than of the untreated biomass 5 . In addition, the ultrasonication of Cotton Gin Trash (CGT) followed by a Liquid Hot Water pretreatment and lignolytic enzymes pretreatment combination generated high amounts of sugar that increased delignification and modified the cellulose structure of the CGT as confirmed by the FT-IR Spectrum $²$
However, a combination of these pretreatments (ultrasonication, Liquid Hot Water and $\mathrm{NaOH}$ hydrolysis), has not been tested in Rice Straw (RS) and Coconut Shell (CS) biomass wastes. Thus, the synergic effect of these technologies may raise de-lignification, cellulose conversion and biogas yield from RS and CS. The effect of these pretreatments over the RS and CS structure can be determined using the Fourier Transform Infrared (FT-IR) spectrum. In principle, FT-IR analysis is applied to study qualitatively the modifications in structure and is not utilized for quantitative analysis. However, it can be used to identify the modification in biomass structure after different pretreatments than the conventional structural examination. From a broad perspective, the requirements of the pretreatment are to 1 . Improve the accessibility of the enzymes to the cellulose and hemicelluloses and thereby the degradability, 2. Avoid degradation or loss of the carbohydrates, 3. Avoid the production of potential process inhibitors, 4. Be cost and energy efficient and 5. Have low negative impact as much as possible on the environment ${ }^{6}$.

Anaerobic co-digestion experiments were performed in this study to provide information on the long-term effects, such as eventual inhibition during the digestion of a lignocellulosic substrate. A co-digestion is often beneficial, since it supplies the system with more nutrients, leading to a better balance in the $\mathrm{C} / \mathrm{N}$ ratio and in the $\mathrm{pH}$. It also improves the stability of the process and increases methane yield due to positive synergistic effects thereby increasing the economic value of the biogas. This study aims to determine the effects of various pretreatment methods (alkalinity using $\mathrm{NaOH}$, ultrasonication, Liquid Hot Water using autoclave) on the biomass properties and biogas yield in the anaerobic co-digestion of agricultural biomass waste utilizing cattle (cow) manure co-digested with different biomass feedstocks such as rice straw, coconut shell and sewage sludge as inoculum for power generation applications.

\section{Materials and Experimental Methods}

\subsection{Experimental Design}

In this study, effects of sequential Alkaline-Ultrasonication and hot water treatment on biogas production from rice straw and coconut shell were determined. The ultrasonication step was modified. It was simultaneously performed with basic hydrolysis using different concen- 
trations ( 3 and $4 \% \mathrm{w} / \mathrm{v})$ of sodium hydroxide $(\mathrm{NaOH})$ solution. The ultrasonicator (Hielscher Ultrasonic Processors, Ringwood, NJ, USA) was set at the highest value of amplitude (100\%) and cycle (1). The biomass was not washed prior to hot water treatment using the autoclave, thus remaining particles of $\mathrm{NaOH}$ can still be present adhering with the biomass. The Liquid Hot Water pretreatment was conducted at $121^{\circ} \mathrm{C}, 1.02 \mathrm{~atm}$ for $1 \mathrm{hr}$. in an autoclave using a feedstock concentration of $10 \%$ solids. The experimental procedure and analysis conducted in this study are shown in Table 1. Control set-ups were conducted using unpretreated rice straw or coconut shell as a substrate in the digester. All the experiments were done in duplicates, with biogas yield and methane concentration as response variables.

Table 1. Summary of test procedures conducted in this study

\begin{tabular}{|l|l|}
\hline \multicolumn{1}{|c|}{ Test Procedures } & \multicolumn{1}{c|}{ ASTM Standards } \\
\hline $\begin{array}{l}\text { Moisture Content } \\
\text { Elemental Analysis }\end{array}$ & E $871-82(2013)$ \\
Carbon and Hydrogen & E 777 - 08 \\
Total Sulfur & E 775 - 15 \\
Nitrogen & E 778 - 15 \\
Oxygen & By Difference \\
Proximate Analysis & \\
VCM & E 872-82 (2013) \\
Ash & E1755 - 01(2015) \\
Fixed Carbon & By Difference \\
Heating Value & E 771 \\
\hline
\end{tabular}

\subsection{Biomass Substrates}

Rice straws were obtained from the Texas A\&M AgriLife Research Center in Beaumont, Texas. Coconuts, on the other hand were bought from the local supermarket in College Station, Texas. The coconut meat was removed and the shells were set aside for further processing. The rice straw and coconut shell samples were ground in a Wiley mill to achieve an average particle size of approximately $1 \mathrm{~mm}$ in diameter.

\subsection{Pretreatment Experiments}

The experiment followed the sequence of pretreat-

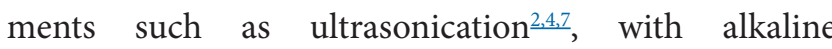
treatment through $\mathrm{NaOH}$ simultaneously ${ }^{3.4 .57}$; and liquid hot water $\frac{2,3,5}{2}$. As shown in Table 2 , rice straw and coconut shell samples were subjected to mechanical disruption using the ultrasonication process. A solution containing $10 \% \mathrm{w} / \mathrm{v}$ solid biomass was put in an ultrasonicator (Hielscher Ultrasonic Processors, Ringwood, NJ, USA) with operating conditions set at the highest value of amplitude $(100 \%)$ and cycle (1). Inside the reactor, ultrasonic waves create cavitation in the liquid medium $(\mathrm{NaOH})$ which contains 250 grams of rice straw sample. Samples in 3,000 ml Erlenmeyer flask were manually stirred, then sonicated for $1 \mathrm{hr}$. After the ultrasonication process, the biomass was not washed prior to hot water treatment. The Liquid Hot Water pretreatment was performed in an autoclave for $1 \mathrm{hr}$ at a temperature of $121^{\circ} \mathrm{C}$ and working pressure of $15 \mathrm{psi}$. The slurry was drained off. The remaining solids were washed with deionized water until the washings were clean, colorless and the $\mathrm{pH}$ was neutral. The rice straw was then dried overnight in an oven at $105^{\circ} \mathrm{C}$. Dried rice straw and coconut shell were stored in polyethylene bags and were used for proximate analysis (total solids, volatile solids and ash), chemical analysis (cellulose, hemicellulose, lignin) using FT-IR. Untreated rice straw and coconut shell were also subjected to analysis to determine the extent of their degradation.

\subsection{Anaerobic Co-Digestion Experiments}

In the present study, batch trials were performed to investigate the effects of biogas production from rice straw and coconut shell substrates subjected to pretreatments such as ultrasonication with $\mathrm{NaOH}$ simultaneously; and

Table 2. Pretreatment conditions evaluated in this study

\begin{tabular}{|c|c|c|c|c|}
\hline Parameters & \multicolumn{2}{|c|}{ Rice Straw } & \multicolumn{2}{c|}{ Coconut Shell } \\
\hline Weight of Biomass (grams) & 250 & 250 & 250 & 250 \\
\hline NaOH Concentration (\% w/v) & 3 & 4 & 3 & 4 \\
\hline Ultrasonication Treatment Conditions & $1 \mathrm{hr}, 100 \%$, cycle (1) & $1 \mathrm{hr} ., 100 \%$, cycle $(1)$ & $1 \mathrm{hr} ., 100 \%$, cycle (1) & $1 \mathrm{hr} ., 100 \%$, cycle (1) \\
\hline Liquid Hot Water Treatment Conditions & $121^{\circ} \mathrm{C}, 1.02 \mathrm{~atm}, 1 \mathrm{hr}$. & $121^{\circ} \mathrm{C}, 1.02 \mathrm{~atm}, 1 \mathrm{hr}$. & $\begin{array}{c}121^{\circ} \mathrm{C}, 1.02 \mathrm{~atm}, \\
1 \mathrm{hr} .\end{array}$ & $121^{\circ} \mathrm{C}, 1.02 \mathrm{~atm}, 1 \mathrm{hr}$. \\
\hline
\end{tabular}


Liquid Hot Water treatment. For each batch trial, reactors were filled with the inoculum, which is cattle manure, and sewage sludge; and co-digested simultaneously with various combinations of biomass like rice straw and coconut shell. Control reactors containing only cattle manure and cattle manure with sewage sludge were maintained during each batch trial. Feed compositions used for the batch trials are given in Table 2. Each reactor had a total working volume of approximately $4.8 \mathrm{~L}$ and duplicate reactors were used for each feed composition. The trials were performed in an environmental chamber maintained at $35^{\circ} \mathrm{C}$. The digesters were mixed daily by turning them upside-down and shaking for about 20 seconds.

Biogas volumes were recorded daily. The gas collectors were marked to provide a direct reading of volume. Biogas was discharged from the gas collectors by lifting the overflow carboy above the collectors to refill the collectors with water and opening the valves on top of the digesters to allow the gas to exit. Gas sampling was done through the use of a tee connection located between the gas collector and digester which were sealed with a rubber stopper. The stopper was removed and a syringe was inserted into the tee to collect a gas sample. While gas was flowing out of the gas collector, the syringe was gradually opened to withdraw a sample. Approximately $60 \mathrm{~mL}$ was collected for each biogas sample which was analyzed immediately using gas chromatography unit (SRI Gas Chromatograph). Gas samples were collected daily during the batch trials. Liquid samples were taken only the first and last days of each batch trial to determine solids content characterization. The liquid samples were collected in duplicate, with approximately $75 \mathrm{~mL}$ of material collected for each sample. The liquid samples are subjected to moisture content determination, proximate, ultimate and heating value analysis.

\subsection{Analytical Methods}

To determine the structural composition of the rice straw biomass before and after the pretreatments, the analytical protocols developed by the National Renewable Energy Laboratory (NREL) of the US Department of Energy were followed. This entails the determination of the total solids in biomass and total dissolved solids in liquid process samples $\stackrel{8}{-}$ the past protocols were developed using dried biomass. Fourier Transform InfraRed (FT-IR) spectroscopy (Shimadzu, IR Affinity-1 with a Miracle universal sampling accessory) was used to evaluate the structural properties of the rice straw and coconut shell with and without pretreatments. The infrared spectra collected range was 4000 to $700 \mathrm{~cm}^{-1}$ with a resolution of $4 \mathrm{~cm}^{-1}$.

\section{Results and Discussions}

\subsection{Biomass Characterization}

The results of the characterization of digestion substrates and inoculum are shown in Table 3. Based on the characterization results, the coconut shell and rice straw potentially be used as a substrate for the biogas production since it has lower nitrogen content $(0.81 \%$ and $0.82 \%)$, which is a factor to consider in order to avoid ammonia inhibition of the digestion process. Aside from that, the digested cow manure and cow manure with rice straw from the previous anaerobic co-digestion experiments are used as inoculums produces a biogas production of $1,100 \mathrm{~mL}$ from the mixture of cattle manure with $3 \%$ $\mathrm{NaOH}$ pretreated rice straw were observed on the 1st day. It indicates that reactors inoculated with $\mathrm{CM}+\mathrm{RS}$ was efficient as well as the digested manures since the inoculum substrates are already acclimatized to the environment conditions of the digester. This effect can be shown on the values of the carbon to nitrogen ratio of the digested manures. The Anaerobic Digestion (AD) experiment used mixtures from different biomass such as cow manure, sewage sludge and inoculum from previous anaerobic co-digestion experiments (i.e. digested cattle manure; digested cattle manure with untreated rice straw). The experimental design was completely randomized to attain a Carbon-to-Nitrogen $(\mathrm{C} / \mathrm{N})$ ratio of the mixture of 25. A control run was done using cow manure as sole substrate. All the experiments were performed in duplicates using methane production and biogas yield as response variables.

The analysis shows a high Volatile Solid Content (VCM) in a coconut shell (92.42\%) and followed by rice straw (66.56\%), sewage sludge (70.38) and cattle manure (48.54) is significantly lower, demonstrating the spent microbial activity from the original process. Cattle manure (77.57\%) showed the disparity of moisture contents, with rice straw (7.20\%) having a low content level. Based on the results reported by ${ }^{9}$, the application of ultrasonic irradiation process can reduce ash content in pretreated rice straw in order to enhance the enzymatic hydrolysis. In addition, the characterization of the biomass substrates and inoculum conducted in this study were comparable 
to the published data of $\frac{10}{}$. Similarly, a study by $\underline{11}$ indicates that the Liquid Hot Water pretreatment is highly effective for enlarging the accessible and susceptible surface area of the cellulose and thus, improving the cellulose degradability to anaerobic microbes and enzymes. The chemical pretreatment by alkalinity using the $\mathrm{NaOH}$ solution is more recommended since the ester bonds of lignin-carbohydrate complexes were destroyed and the intermolecular linkages and functional groups surrounding the holocelluloses, lignin, cellulose and hemicellulose were either broken down or destroyed $\frac{11,12}{1}$. However, there is inadequate to limited literature with regards to the pretreatments of coconut shell using the alkalinity using $\mathrm{NaOH}$, ultrasonication and liquid hot water.

\subsection{Biomass Pretreatment}

The rice straw and coconut shell were subjected to a sequence of pretreatments such as ultrasonication with alkaline treatment through $\mathrm{NaOH}$ simultaneously; Liquid Hot Water through the autoclave. However, the ultrasonication step for this experiment was modified to simultaneously perform a basic hydrolysis using different concentrations of $\mathrm{NaOH}$ ( 3 and $4 \% \mathrm{w} / \mathrm{v}$ ) and a control of untreated rice straw as shown in Table 1 . These values were selected to avoid producing a waste chemical solution and also to reduce the pretreatment cost (Zhang et al., 2015). Another study in the literature reported that $3-4 \%$ is the optimal dose for five $\mathrm{NaOH}$ samples $(2,4,6$, 8 and 10\%) when was used to pretreat rice straw digest- ibility and biogas production $\frac{3,11}{1}$. Series of test and analysis for untreated and pretreated rice straw and coconut shells were conducted, such as \% total solids and moisture content determination through proximate and ultimate analysis as shown in Table 4. The analysis shows VCM content in rice straw is significantly higher than the untreated ones. In fact, the untreated rice straw increased VCM content from $66.56 \%$ to $84.73 \%$ and $88.18 \%$, for the $3 \%$ $\mathrm{NaOH}+\mathrm{U}+\mathrm{LHW}$ RS and $4 \% \mathrm{NaOH}+\mathrm{U}+\mathrm{LHW}$ RS respectively. Also, the carbon content of the pretreated coconut shell is higher than the pretreated rice straw by $7.25 \%$ points and $8.84 \%$ points for $3 \%$ and $4 \% \mathrm{NaOH}+\mathrm{U}+\mathrm{LHW}$ pretreatment respectively. The total solid content determination was conducted in duplicates, while moisture content determination was done in triplicates based on the ASTM E1756 standard.

As shown in Table 4, the pretreatment (using Alkaline-Ultrasonication and Liquid Hot Water using autoclave) of rice straw and coconut shell with $3 \% \mathrm{w} / \mathrm{v}$ $\mathrm{NaOH}$ concentration $(3 \% \mathrm{NaOH}+\mathrm{U}+\mathrm{LHW}$ RS and $3 \%$ $\mathrm{NaOH}+\mathrm{U}+\mathrm{LHW} \mathrm{CS}$ ), yielded the highest heating value, followed by the $4 \% \mathrm{NaOH}(4 \% \mathrm{NaOH}+\mathrm{U}+\mathrm{LHW}$ RS and $3 \% \mathrm{NaOH}+\mathrm{U}+\mathrm{LHW} \mathrm{CS})$. An additional examination was conducted on the ultimate, proximate analysis and heating value for the untreated and pretreated rice straw and coconut as well as the sewage sludge and cattle manure. Therefore, the said biomass samples are quite combustible in nature, as compared with the untreated rice straw. The amount of the Volatile Combustible Matter increases 30\%

Table 3. Characterization of the biomass and inoculum used during the anaerobic digestion

\begin{tabular}{|l|c|c|c|c|c|c|}
\hline \multicolumn{1}{|c|}{ Property } & $\begin{array}{c}\text { Cattle Manure } \\
(\mathbf{C M})\end{array}$ & $\begin{array}{c}\text { Sewage Sludge } \\
(\text { SS })\end{array}$ & $\begin{array}{c}\text { Rice Straw } \\
(\mathbf{R S})\end{array}$ & $\begin{array}{c}\text { Coconut Shell } \\
(\mathbf{C S})\end{array}$ & $\begin{array}{c}\text { Inoculum1 } \\
(\mathbf{C M})\end{array}$ & $\begin{array}{c}\text { Inoculum 2 } \\
(\mathbf{C M}+\mathbf{R S})\end{array}$ \\
\hline Moisture (\%) & 77.57 & 96.43 & 7.20 & 22.29 & 86.88 & 80.72 \\
\hline TS (\%) & 54.61 & 1.92 & 96.69 & 81.71 & 106.88 & 158.45 \\
\hline VCM (\%) & 48.54 & 70.38 & 66.56 & 92.42 & 83.05 & 107.58 \\
\hline Ash (\%) & 12.70 & 1.50 & 12.90 & 16.9 & 23.82 & 50.88 \\
\hline Fixed Carbon (\%) & 15.90 & 35.10 & 19.10 & 0.80 & 3.52 & 16.14 \\
\hline C (\%TS) & 21.64 & 36.17 & 33.71 & 45.21 & 39.02 & 37.86 \\
\hline H (\%TS) & 2.83 & 5.13 & 4.73 & 5.93 & 0.00 & 5.25 \\
\hline O (\%TS) & 73.51 & 51.36 & 60.54 & 47.83 & 59.84 & 55.14 \\
\hline N (\%TS) & 0.84 & 6.32 & 0.81 & 0.86 & 1.14 & 1.38 \\
\hline S (\%TS) & 1.18 & 1.02 & 0.20 & 0.17 & 0.00 & 0.37 \\
\hline C:N Ratio & 25.86 & 5.73 & 41.88 & 52.57 & 34.16 & 27.47 \\
\hline Heating Value (MJ/kg) & 16.99 & 18.81 & 13.59 & 18.51 & 17.22 & 13.34 \\
\hline
\end{tabular}


more than the untreated ones. The said pretreatments can be interpreted that the lignin component of the rice straw is degraded during the pretreatments. However, it needs further verification by conducting FTIR analysis of the pretreated samples as discussed in the next section.

Table 4. Characterization of the treated biomass during the anaerobic digestion

\begin{tabular}{|l|l|l|l|l|}
\hline \multicolumn{1}{|c|}{ Property } & $\begin{array}{c}\text { Rice } \\
\text { Straw } \\
3 \% \mathrm{w} / \mathrm{v}\end{array}$ & $\begin{array}{c}\text { Rice } \\
\text { Straw } \\
4 \% \mathrm{w} / \mathrm{v}\end{array}$ & $\begin{array}{c}\text { Coconut } \\
\text { Shell } \\
3 \% \mathrm{w} / \mathrm{v}\end{array}$ & $\begin{array}{c}\text { Coconut } \\
\text { Shell } \\
4 \% \mathrm{w} / \mathrm{v}\end{array}$ \\
\hline VCM (\%) & 84.73 & 88.18 & 78.85 & 78.19 \\
\hline Ash (\%) & 11.26 & 4.79 & 18.78 & 19.55 \\
\hline $\begin{array}{l}\text { Fixed Carbon } \\
\text { (\%) }\end{array}$ & 4.01 & 7.03 & 2.37 & 2.26 \\
\hline C (\%TS) & 39.33 & 37.23 & 46.58 & 46.07 \\
\hline H (\%TS) & 5.76 & 5.48 & 5.77 & 5.64 \\
\hline O (\%TS) & 54.58 & 57.06 & 47.42 & 48.06 \\
\hline N (\%TS) & 0.04 & 0.02 & 0.02 & 0.02 \\
\hline S (\%TS) & 0.28 & 0.22 & 0.20 & 0.22 \\
\hline C:N Ratio & 936.50 & 2326.56 & 1940.79 & 2879.19 \\
\hline $\begin{array}{l}\text { Heating Value } \\
\text { (MJ/kg) }\end{array}$ & 15.76 & 13.08 & 19.28 & 19.33 \\
\hline
\end{tabular}

\subsection{Analysis of the Biomass Substrate using FT-IR}

To understand the changes in the substrate after pretreatment, substrate characteristic analysis was performed. The alterations in the lignocellulose after pretreatment will affect the subsequent anaerobic digestion and studying these modifications by different characterization methods could predict the outcome of biogas production. The increase in biodegradability of a biomass can partly be explained by a decrease in the crystallinity of the cellulose fibers. This characteristic was measured by Fourier Transform Infrared Spectroscopy (FTIR), having wave number of $1320 / 898 \mathrm{~cm}^{-1}$ for rice straw and $898 \mathrm{~cm}^{-1}$ for coconut shell. The analyzed compounds and their IR wave numbers are enumerated in Table 5 and 6 . The analyzed peaks (Figures 1-2) were seen in the control and in the pretreated samples of rice straw and coconut shell spectra's. The highest peaks in all the samples are the ones related to cellulose $\left(1320 \mathrm{~cm}^{-1}\right)$ for rice straw, which also have the highest variation among the pretreatments. The principal variation in the cellulose peaks is presented in the $(1320$ and $\left.1645 \mathrm{~cm}^{-1}\right)$ for rice straw and $\left(1240\right.$ and $\left.1730 \mathrm{~cm}^{-1}\right)$ for coconut shell. These pretreatment peaks increased the strength of the signal compared with the control rice straw and coconut shell. The $\mathrm{NaOH}$-ultrasonication and Liquid Hot Water pretreatments showed the highest differences in signals compared with the biomass that was not subjected to any pretreatment.

The reduction in the lignin signals of pretreated rice straw was principally observed in the $1645 \mathrm{~cm}^{-1}$ spectrum. This reduction is related to the modification of the lignin aromatic skeletal structure generated in the pretreatments mixture. Additionally, the coconut shell pretreatments made an important reduction in the bands near $1,500 \mathrm{~cm}^{-1}$, where the band is associated with the aromatic $\mathrm{C}-\mathrm{H}$ region of lignin. The said results are consistent with the results reported in ${ }^{12-14}$, wherein the $\mathrm{NaOH}$-treated rice straw increased the biogas production by $27.3-64.5 \%$; and this was attributed to the improvement of the degradability of the rice straw through $\mathrm{NaOH}$ pretreatments since Lignin-Carbohydrate Complexes (LCC) was destroyed throughout the hydrolysis reaction, releasing more cellulose for biogas production ${ }^{4}$. Similarly, a decrease in the crystallinity of cellulose fibers increases the biodegradability of rice straw ${ }^{14}$. Likewise, the association of lignin with holocelluolose decreased; and the cellulose and hemicellulose were degraded with $\mathrm{NaOH}$ treatment that enabled the rice straw to be easily accessed, attacked and digested by anaerobic bacteria and enhanced the biodegradability of the rice straw and methane production ${ }^{13}$. The hemicellulose signals showed the most variable behavior. In $1240 \mathrm{~cm}^{-1}$ and $1730 \mathrm{~cm}^{-1}$ signal, the $\mathrm{U}+\mathrm{NaOH}+\mathrm{LHW}$ pretreatments using coconut shell biomass presents an increment in the absorbance. After the pretreatments, it shows a reduction in the signal of 1730 $\mathrm{cm}^{-1}$ and any effect over the $1240 \mathrm{~cm}^{-1}$. Likewise, the pretreated rice straw has not shown the wavelength near the $1730 \mathrm{~cm}^{-1}$ region. The variation in the signal intensity of $1730 \mathrm{~cm}^{-1}$ can be related to major exposure of the hemicellulose in the coconut shell biomass, which increased the absorption in the spectrum. This major exposure can be explained as the pretreatments resulted in modification of the hemicellulose structure or disrupted some of the linkages between the hemicellulose and cellulose or lignin. Also, the reduction in this signal can be related to the inversion of sugars from the hemicellulose in the liquid medium and propitiate a reduction of this signal in the biomass. This kind of reduction in hemicellulose was also found in acid hydrolysis of cotton stalks $\frac{15}{}$. 
Table 5. Wave numbers of IR vibration frequencies used for rice straw characterization

\begin{tabular}{|l|l|l|}
\hline $\begin{array}{c}\text { Wave Number } \\
\left(\mathbf{c m}^{-1}\right)\end{array}$ & Compound & \multicolumn{1}{|c|}{ Functional Groups } \\
\hline 3335 & a-cellulose & $\begin{array}{l}\text { Hydrogen bond hydroxyl } \\
\text { (Alcohol/Phenol), O-H bond } \\
\text { stretch }\end{array}$ \\
\hline 2920 & Lignin & Alkane (alkyl), C-H stretch \\
\hline 1645 & Lignin & $\begin{array}{l}\text { Conjugated carbonyl } \\
\text { (amide), C=O Stretch }\end{array}$ \\
\hline 1320 & Cellulose & $\begin{array}{l}\text { C-H plane bending of } \\
\text { cellulose I and cellulose II }\end{array}$ \\
\hline 898 & Cellulose & $\beta$-D- cellulose \\
\hline
\end{tabular}

Table 6. Wave numbers of IR vibration frequencies used for coconut shell characterization

\begin{tabular}{|l|l|l|}
\hline $\begin{array}{c}\text { Wave Number } \\
\left(\mathbf{c m}^{-1}\right)\end{array}$ & \multicolumn{1}{|c|}{ Compound } & \multicolumn{1}{|c|}{ Functional Groups } \\
\hline 3340 & a-cellulose & $\begin{array}{l}\text { Hydrogen bond hydroxyl } \\
\text { (Alcohol/Phenol), O-H } \\
\text { bond stretch }\end{array}$ \\
\hline 2930 & Lignin & $\begin{array}{l}\text { Alkane (Alkyl), C-H } \\
\text { stretch }\end{array}$ \\
\hline 1730 & Hemicellulose & Ester Carbonyls, C=O stretch \\
\hline 1592 & Lignin & Aromatic, C-H deformation \\
\hline 1240 & Hemicellulose & $\begin{array}{l}\text { Ester Carbonyls, C=O } \\
\text { stretch }\end{array}$ \\
\hline 897 & Cellulose & $\beta$-D- cellulose \\
\hline
\end{tabular}

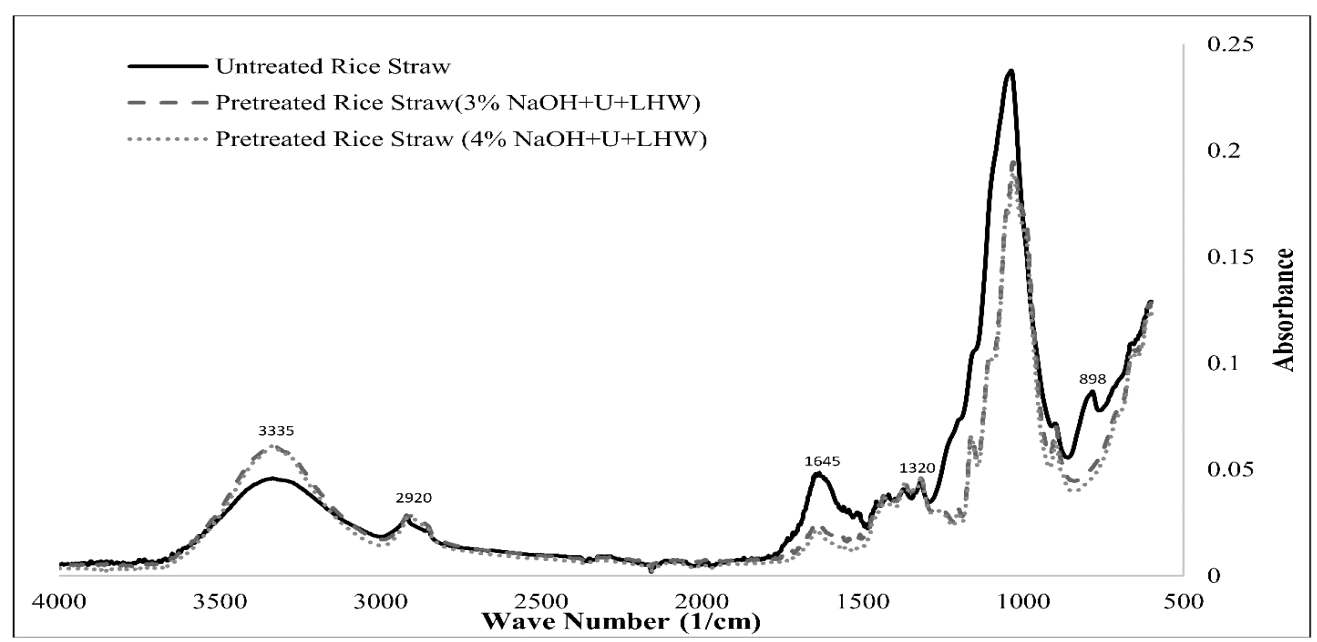

Figure 1. FT-IR spectra of rice straw, untreated and upon subjected to sequential $\mathrm{NaOH}-$ Ultrasonication and Liquid Hot Water treatment.

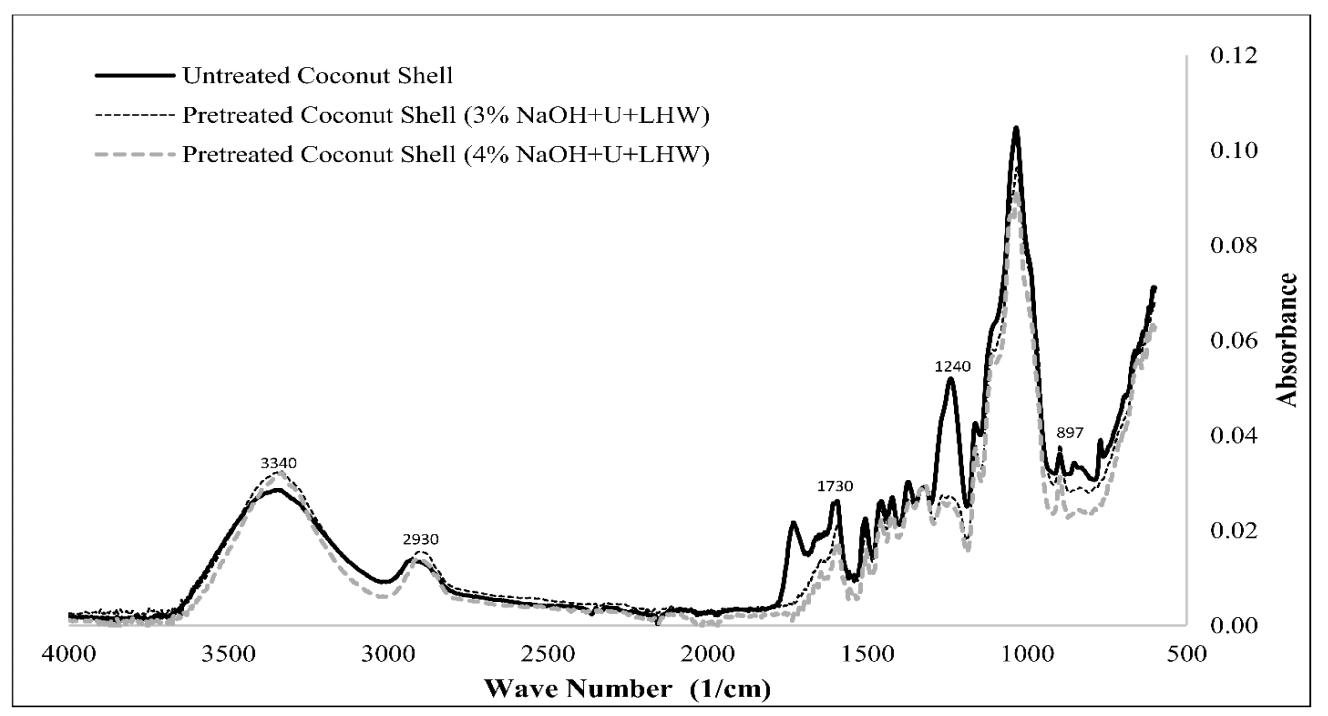

Figure 2. FT-IR spectra of coconut shell, untreated and upon subjected to sequential $\mathrm{NaOH}$ Ultrasonication and Liquid Hot Water treatment. 


\subsection{Methane Quality}

In this research, the effects of applying pretreatments using the Alkaline-Ultrasonication hydrolysis and Liquid Hot Water on the co-digestion of dairy cattle manure with rice straw and coconut shell, compared with the untreated residues, were determined. The said experiment undergoes 45 days of the anaerobic co-digestion process. The biogas production from rice straw and coconut shell subjected to four (4) pretreatments (i.e. Alkaline-Ultrasonication Hydrolysis and Liquid Hot Water using autoclave pretreatments with varying $\mathrm{NaOH}$ concentration of $3 \%$ and $4 \% \mathrm{w} / \mathrm{v}$ ) were monitored. Figure 3 shows that the pretreated rice straw $(\mathrm{CM}+\mathrm{RS} 1$ and $\mathrm{CM}+\mathrm{RS} 2)$ produces higher biogas production than other pretreatments and the same effect was achieved in the pretreatment of the coconut shell, whereas $23.12 \mathrm{~L}$ of gas was produced (Table 7). The biogas production with co-digestion of rice straw is 1.89 times higher than the untreated ones and 1.50 times higher than the untreated coconut shell.

Similarly, the percent methane concentration on the different treatments shown in Figure 4 maintains in the $50 \%$ mark except for the cow manure which slightly decreased as observed on 10th to 12th day. Likewise, similar reports were reported by ${ }^{16}$ in the anaerobic codigestion of cow manure at various maceration times which resulted in a methane concentration of $58 \%$ from the co-digestion of cow manure with rice straw. Moreover, the average percent methane concentration for these treatments presented in Figure 4 are also in the 50\% mark as compared to the untreated rice straw and coconut shell that it took 25 days in order to reach the $50 \%$ methane concentration. Likewise, the methane concentration on all the biogas treatments reaches above $50 \%$ on its fourth day and readings maintain with slight variations and reported same levels with other publications $\frac{10,16}{}$. This implies that fermentation/anaerobic digestion process properly converts the waste organic matter into a mixture of carbon dioxide and methane gas ${ }^{17}$. Methane production trends of the treated and pretreated biomass shown in Figure 5 follows similar production trends for all the digesters. In 5 days, methane production rates using treated biomass had increased over the initial production rates (Day 4) compared with the untreated ones for more than $300 \%$. Hence, co-digestion of pretreated biomass helps to overcome the deficiencies of mono-digestion, which typically become the rate limiting step for the $\mathrm{AD}$ process ${ }^{11,18}$. Thus, anaerobic co-digestion of different organic materi- als may enhance the stability of the anaerobic processes $\underline{19}$ because of better carbon-to-nitrogen balance. In addition, co-digestion can alleviate the inhibitory effect of high ammonia and sulfide concentrations $s^{19}$ and exhibits a more stable biogas production.

Table 7.45-days digestion results of pretreated agricultural residues with cow manure

\begin{tabular}{|l|c|c|c|c|}
\hline \multicolumn{1}{|c|}{ Parameter } & \multicolumn{2}{c|}{$\begin{array}{c}\text { Cattle Manure + } \\
\text { Rice Straw }\end{array}$} & \multicolumn{2}{c|}{$\begin{array}{c}\text { Cattle Manure + } \\
\text { Coconut Shell }\end{array}$} \\
\hline & $3 \% \mathrm{w} / \mathrm{v}$ & $4 \% \mathrm{w} / \mathrm{v}$ & $3 \% \mathrm{w} / \mathrm{v}$ & $4 \% \mathrm{w} / \mathrm{v}$ \\
\hline C/N ratio & 27.05 & 27.03 & 24.79 & 24.79 \\
\hline Biogas Yield (L) & 18.18 & 12.54 & 23.12 & 8.44 \\
\hline Methane Yield (L) & 9.88 & 6.96 & 13.84 & 4.77 \\
\hline $\begin{array}{l}\text { Average Methane } \\
\text { content (\%) }\end{array}$ & 53.80 & 53.00 & 55.90 & 54.50 \\
\hline
\end{tabular}

\subsection{Biogas Production}

As shown in Figure 3, the gas production for the different treatments (i.e. $\mathrm{CM}, \mathrm{CM}+\mathrm{RS}$, etc.) conditions. Under the mesophilic conditions, production of gases for the pretreatments was higher than the untreated ones. Compared with the study of ${ }^{18}$, the mesophilic AD processes produced more methane rather than digesting at ambient temperature conditions. Based from that, it can be proved that temperature plays an important role in digesting rice straw from a mixture of cow manure $\frac{18}{}$. Applying Alkaline-Ultrasonication and Liquid Hot Water pre-treatments for the rice straw and coconut shell transforms this biomass into digestible carbon with minimal nitrogen component. This confirms to the results of $\frac{20}{}$, that using pretreatments (i.e. sonication) can lead to best results for both biogas and methane production. During the first 3 days, a rapid increase in of biogas production was observed ranging from $500 \mathrm{~mL}$ up to 2 liters per day. The reason for this is the digester imbalance due to the excessive changes in temperature, a sudden increase in organic loading or a change in feed characteristics ${ }^{17}$, in which case these two (organic loading, feed characteristics) falls in this category. If these upsets continue, these can lead to digester failure causing a loss in biogas production for extended periods of time, in which, it was depicted from Day 4 until Day 9, (excluding the production of biogas from cattle manure (control) that increased until Day 14). This indicates that the process upset actually happens to the digester. It may result from volumetric overload due to instability of the biogas reaction. The bio- 


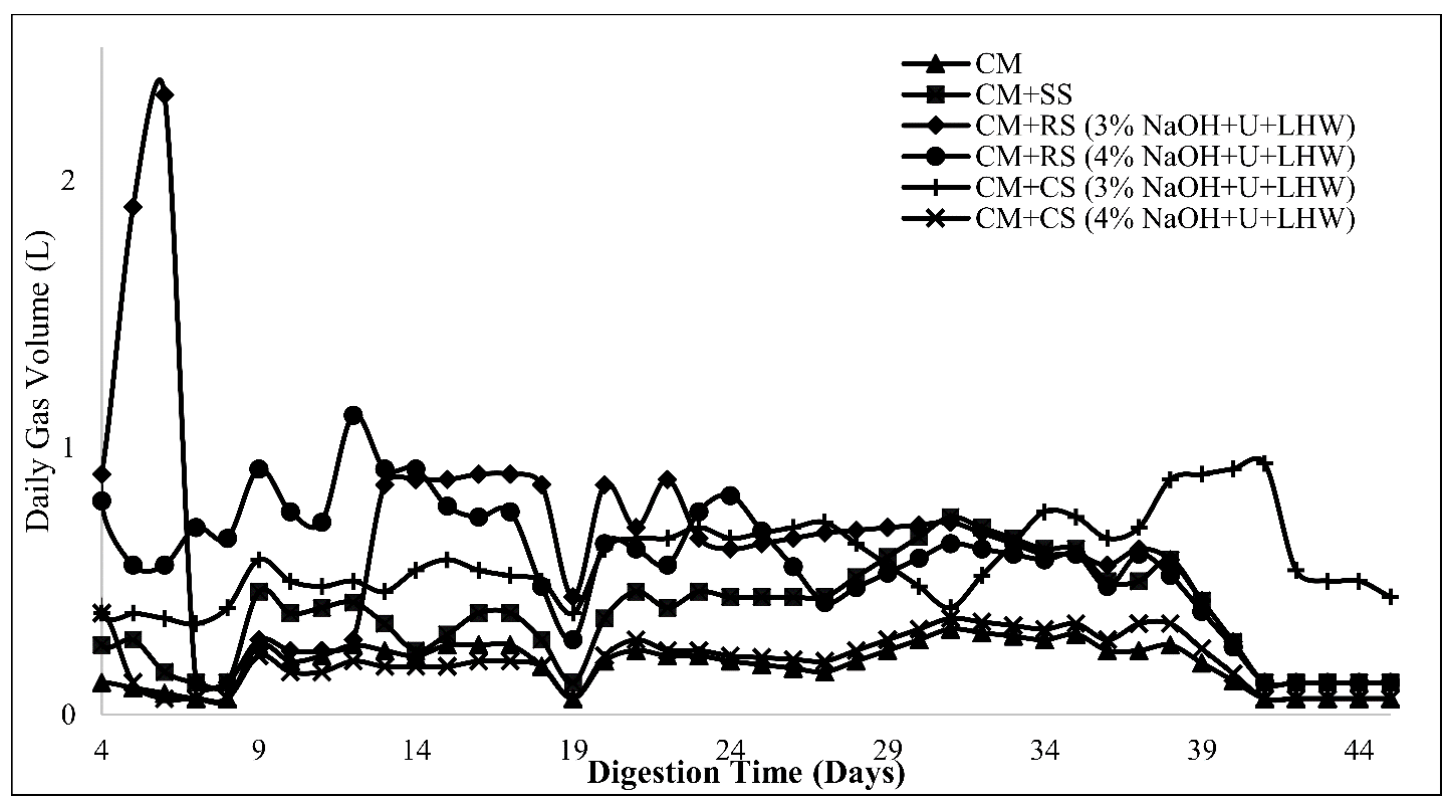

Figure 3. Average daily biogas production from solely cattle manure and from mixture of cattle manure and pretreated rice straw or coconut shell,

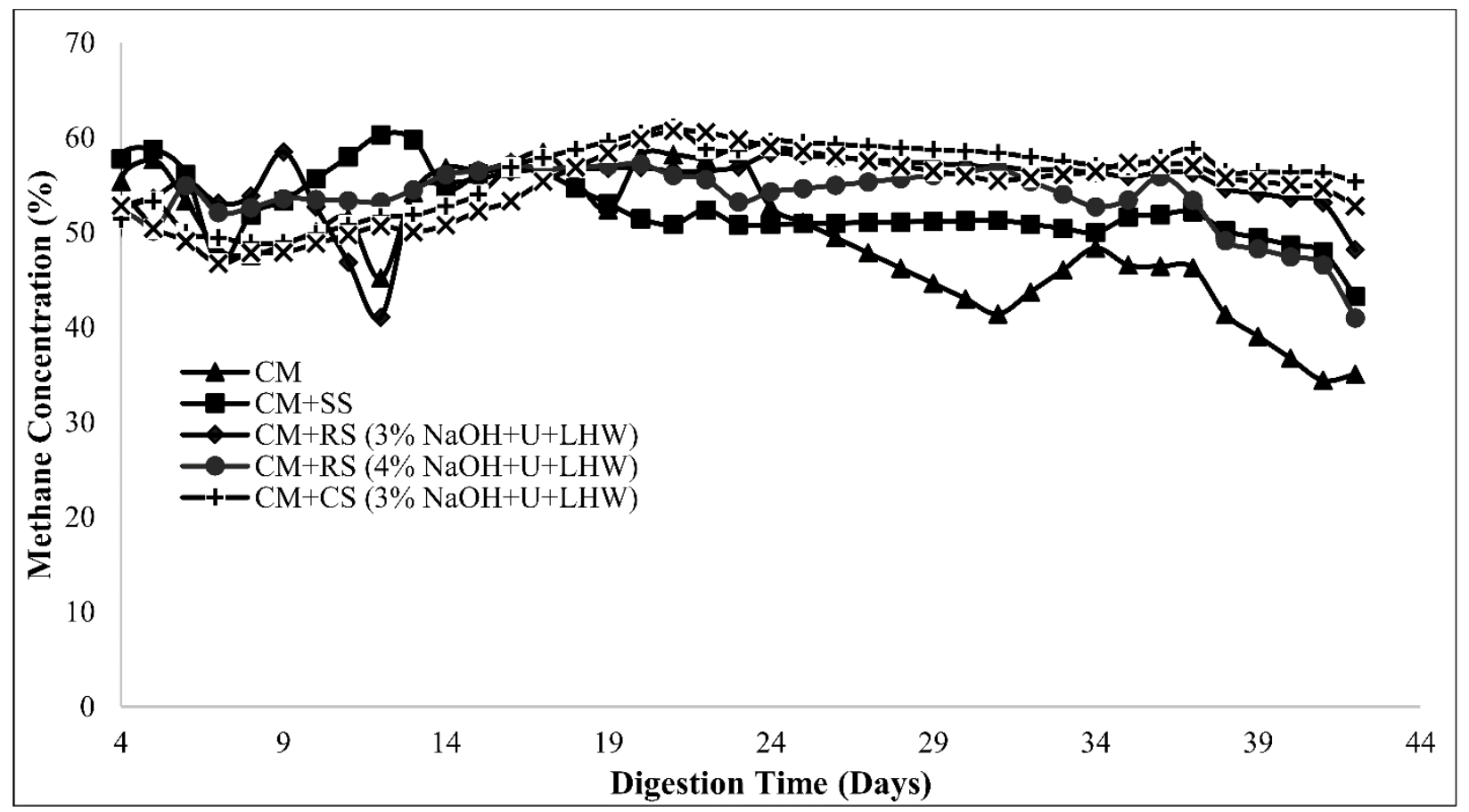

Figure 4. Average methane concentration after 45-day anaerobic digestion of solely cattle manure and mixture of cattle manure and pretreated rice straw or coconut shell.

gas production in the next few days were recovered and maintained at a certain level.

Based on these results, pretreatments of the biomass using the Alkaline-Ultrasonication and Liquid Hot Water pretreatment were effective on the production of biogas and digesting bacteria does not need lag phase $\mathrm{i}^{14}$ to convert the treated rice and coconut shell into biogas. At the same time, pretreated agricultural residues produced higher methane concentration than the untreated ones. This improvement on biogas production is most likely 


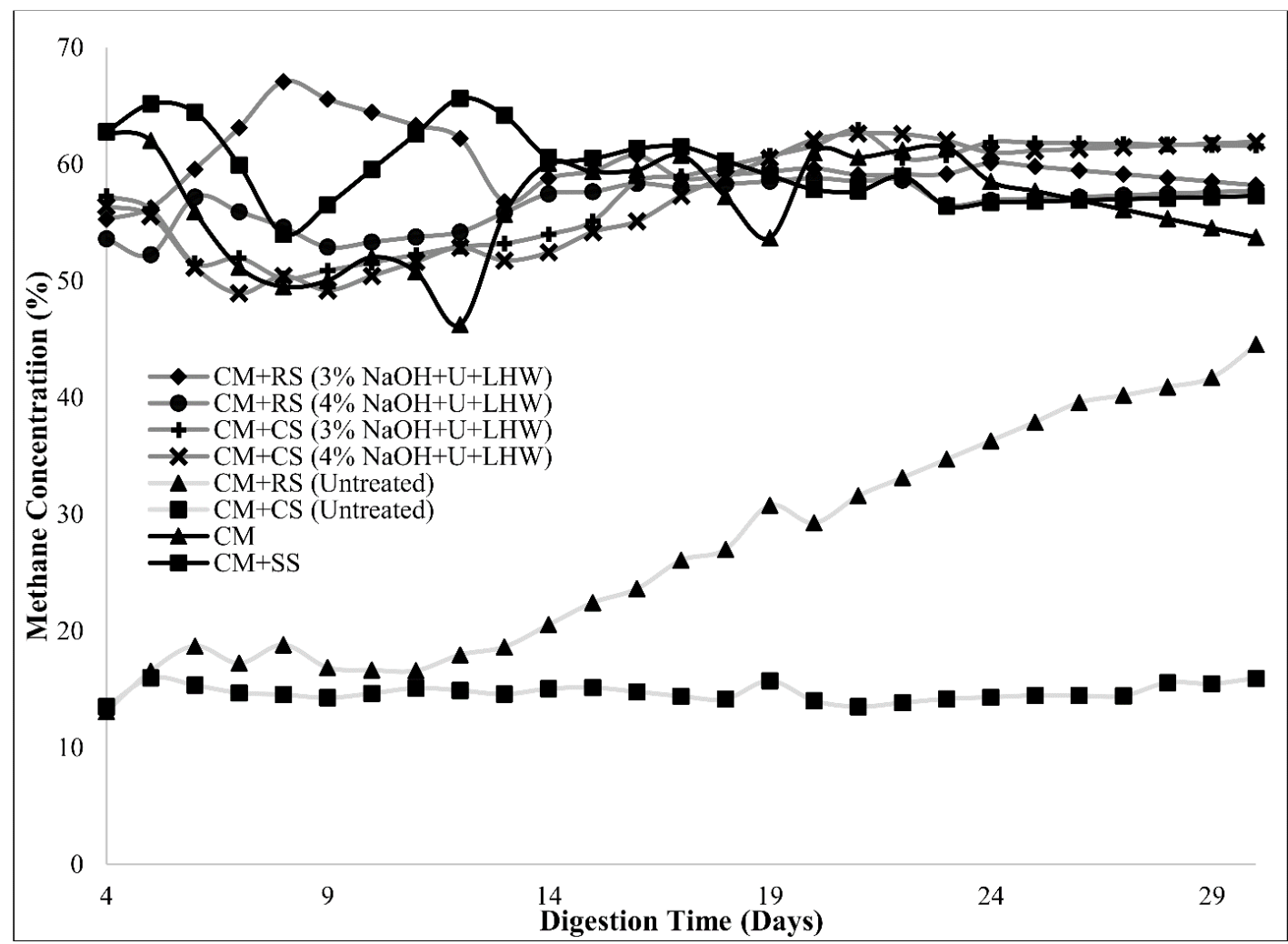

Figure 5. Average methane concentration after 45-day anaerobic digestion of solely cattle manure and mixture of cattle manure and pretreated rice straw or coconut shell.

due to the breakdown of the crystalline structure of the lignocelluloses and consequently due to the higher accessibility of the bacteria to the cellulose and hemicellulose $e^{\frac{14}{4}}$. Likewise, the hydrolysis of lignocellulosic biomass is the rate limiting step in anaerobic digestion and pretreatment improves digestion efficiency and biogas production ${ }^{21}$.

\subsection{Effects of Balanced Carbon-to-Nitrogen $(\mathrm{C} / \mathrm{N})$ Ratio}

As seen in Figure 4, the rice straw pretreated with 4\% w/v NaOH solution with ultrasonication and Liquid Hot Water using autoclave $(\mathrm{U}+\mathrm{LHW})$ reached the highest volumetric biogas production beginning Day 1 of digestion, as opposed to other treatments, and peaked by Day 3 (1.34 Lday $\left.^{-1}\right)$ and $\left(2.06\right.$ Lday $\left.^{-1}\right)$ before descending on Day 7. In contrast, the digester with pretreated coconut shell also recorded its highest gas production on Day 3 (1.62 Lday $\left.^{-1}\right)$. The control digester produced the least biogas among all tested samples with the highest daily volume not exceeding $2 \mathrm{~L}$. It was observed that the biogas productivity was increased for all the pretreated biomass with maximum daily volumes of $1.34 \mathrm{~L}, 2.06 \mathrm{~L}$ and $2.26 \mathrm{~L}$ for rice straw, as compared to $1.62 \mathrm{~L}$, for the coconut shell, respectively. Rice straw produced more biogas than coconut shell up to Day 6 and being on par with coconut shell on Day 23 to 27 (Figure 4). From Day 19 to the end of the duration of the experiment, although the total daily biogas volume produced by coconut shell was not statistically higher than either rice straw and cow manure, the mean volumes were still outstripping the other two, making coconut shell the most productive additive in improving biogas production among the three tested materials when co-digested with cow manure at a $\mathrm{C} / \mathrm{N}$ ratio of 24.79 . Although, it was suggested that the suitable range of $\mathrm{C} / \mathrm{N}$ ratio should be around 20-30 in AD process to avoid inhibition due to indigestibility of the lignocellulose material. This shows that co-digestion of pretreated crop residues with animal manure increases volumetric biogas yields, higher than previously reported $\frac{10,18}{\text {. }}$.

The $\mathrm{CH}_{4}$ content in all the treatments including the control was relatively stable even though it reached the respective peak levels. Although the pretreated rice straw and coconut shell (at $4 \% \mathrm{NaOH}$ and Liquid Hot Water) 
produced better results in terms of percent $\mathrm{CH}_{4}$ in the first five sampling days, there was little statistical difference in average $\mathrm{CH}_{4}$ volume produced between these two treatments over the experimental period because rice straw had higher biogas productivity in the early sampling days than untreated ones. Generally, both rice straw and coconut shell worked equally well in terms of increasing the $\mathrm{CH}_{4}$ content given the $\mathrm{C} / \mathrm{N}$ ratio of 25 and 27 (Table 7). However, in the last four sampling days (Day 34-37), the $\mathrm{CH}_{4}$ content in biogas generated from the $4 \%$ $\mathrm{NaOH} \mathrm{U}+\mathrm{LHW}$ pretreated coconut shell was consistently higher than that from the digester treated with rice straw (57.31\% and $57.19 \%$ versus $52.69 \%$ and $53.35 \%$ ), implying that using $4 \% \mathrm{NaOH} \mathrm{U}+\mathrm{LHW}$ pretreatment of rice straw and coconut shell as a co-digestion substrate with cow manure could increase the methane content in the biogas by roughly $7 \%$ as opposed to using rice straw, and $350 \%$ for the untreated coconut shell which was significant. It was also observed that unlike the scenario in the $\mathrm{C} / \mathrm{N}$ ratio of $24.79 / 1$ and $27.03 / 1$ and the $\mathrm{NaOH}$ concentration of $3 \%$ and $4 \%$ with $\mathrm{U}+\mathrm{LHW}$ pretreatment, has no statistical difference in $\mathrm{CH}_{4}$ content among all the treatments (a clear advantage of adding pretreated rice straw and coconut shell over untreated ones which virtually different than the control) to cow manure anaerobic digestion at a $\mathrm{C} / \mathrm{N}$ of 25 .

\section{Conclusion}

This study focuses on the possible means of increasing methane production potential from anaerobic co-digestion of agricultural biomass waste. In agreement with results presented, it showed a positive impact on biogas production rate by biomass pretreatment using $\mathrm{NaOH}$-Ultrasonication and Liquid Hot Water pretreatment. The alkali-ultrasonication-Liquid Hot Water $(\mathrm{NaOH}+\mathrm{U}+\mathrm{LHW})$ pretreatment improved the cellulose and lignocellulose conversion and resulted in methane yields increase of $140 \%$ and $290 \%$ from anaerobic codigestion of rice straw and coconut shell with cow manure and sewage sludge as inoculum compared with untreated material. The use of FT-IR was effective as a tool to identify the variations in the signal of the cellulose, hemicellulose and lignin from rice straw and coconut shell after subjecting into different pretreatments. The study can be recommended in the investigation on the longterm effects in a continuous co-digestion process where lignocelluloses are substrates being utilized. Also, limited research has been performed on the characteristics of substrates of anaerobic digestion. This study also shows how substrate composition, pretreatment methods and operational parameters during anaerobic digestion affect the microbial consortia working in the digester.

\section{References:}

1. Bagher AM. Advantages and disadvantages of biogas energy. Bulletin of Advanced Scientific Research. 2015; 1(5):132-5.

2. Placido J, Imam T, Capareda S. Evaluation of ligninolytic enzymes, ultrasonication and Liquid Hot Water as pretreatments for bioethanol production from cotton gin trash. Bioresource Technology. 2013; 139:203-8. PMid: 23665215. Crossref.

3. Kaur K, Phutela UG. Enhancement of paddy straw digestibility and biogas production by sodium hydroxide-microwave pretreatment. Renewable Energy. 2016; 92:178-84. Crossref.

4. Karray R, Hamza M, Sayadi S. Evaluation of ultrasonic, acid, thermo-alkaline and enzymatic pre-treatments on anaerobic digestion of Ulva rigida for biogas production. Bioresource Technology. 2015; 187:205-13. PMid: 25855526. Crossref.

5. Jiang D, Ge X, Zhang Q, Li Y. Comparison of Liquid Hot Water and alkaline pretreatments of giant reed for improved enzymatic digestibility and biogas energy production. Bioresource Technology. 2016; 216:60-8. PMid: 27233098. Crossref.

6. Philippoussis A, Zervakis G, Diamantopoulou P. Bioconversion of agricultural lignocellulosic wastes through the cultivation of the edible mushrooms Agrocybeaegerita, Volvariellavolvacea and Pleurotus spp. World Journal of Microbiology and Biotechnology. 2001; 17(2):191-200. Crossref.

7. $\mathrm{Oz}$ NA, Uzun AC. Ultrasound pretreatment for enhanced biogas production from olive mill wastewater. Ultrasonicssono Chemistry. 2015; 22:565-72. PMid: 24880765. Crossref.

8. Sluiter A, Hames B, Ruiz R, Scarlata C, Sluiter J, Templeton D, Crocker D. Determination of structural carbohydrates and lignin in biomass. Laboratory Analytical Procedure. 2008; 1617:1-6.

9. Yang CY, Fang TJ. Combination of ultrasonic irradiation with ionic liquid pretreatment for enzymatic hydrolysis of rice straw. Bioresource Technology. 2014; 164:198-202. PMid: 24859211. Crossref. 
10. Gu Y, Chen X, Liu Z, Zhou X, Zhang Y. Effect of inoculum sources on the anaerobic digestion of rice straw. Bioresource Technology. 2014; 158:149-55. PMid: 24589383. Crossref.

11. Zhang W, Wei Q, Wu S, Qi D, Li W, Zuo Z, Dong R. Batch anaerobic co-digestion of pig manure with dewatered sewage sludge under mesophilic conditions. Applied Energy. 2014; 128:175-83. Crossref.

12. He Y, Pang Y, Liu Y, Li X, Wang K. Physicochemical characterization of rice straw pretreated with sodium hydroxide in the solid state for enhancing biogas production. Energy and Fuels. 2008; 22(4):2775-81. Crossref.

13. Zhang Y, Chen X, Gu Y, Zhou X. A physicochemical method for increasing methane production from rice straw: Extrusion combined with alkali pretreatment. Applied Energy. 2015; 160:39-48. Crossref.

14. Teghammar A, Chandra R, Saddler JN, Taherzadeh MJ, Horvath IS. Substrate characteristic analysis for anaerobic digestion: A study on rice and triticale straw. Bio Resources. 2012; 7(3):3921-34.

15. Silverstein RA, Chen Y, Sharma-Shivappa RR, Boyette $\mathrm{MD}$, Osborne J. A comparison of chemical pretreatment methods for improving saccharification of cotton stalks. Bioresource Technology. 2007; 98(16):3000-11. PMid: 17158046. Crossref.
16. Silvestre G, Gomez MP, Pascual A, Ruiz B. Anaerobic codigestion of cattle manure with rice straw: Economic and energy feasibility. Water Science and Technology. 2013; 67(4):745-55. PMid: 23306251. Crossref.

17. Sterling MC. Jr, Lacey RE, Engler CR, Ricke SC. Effects of ammonia nitrogen on $\mathrm{H}_{2}$ and $\mathrm{CH}_{4}$ production during anaerobic digestion of dairy cattle manure. Bio Resource Technology. 2001; 77(1):9-18. Crossref.

18. Lianhua L, Dong L, Yongming S, Longlong M, Zhenhong Y, Xiaoying K. Effect of temperature and solid concentration on anaerobic digestion of rice straw in South China. International Journal of Hydrogen Energy. 2010; 35(13):7261-6. Crossref.

19. Zhang C, Xiao G, Peng L, Su H, Tan T. The anaerobic codigestion of food waste and cattle manure. Bioresource Technology. 2013; 129:170-6. PMid: 23246757. Crossref.

20. Quiroga G, Castrillon L, Fernandez-Nava Y, Mara-on E, Negral L, Rodriguez-Iglesias J, Ormaechea P. Effect of ultrasound pre-treatment in the anaerobic co-digestion of cattle manure with food waste and sludge. Bioresource Technology. 2014; 154:74-9. PMid: 24384312. Crossref.

21. Brown D, Shi J, Li Y. Comparison of solid-state to liquid anaerobic digestion of lignocellulosic feedstocks for biogas production. Bioresource Technology. 2012; 124:379-86. PMid: 22995169. Crossref. 